\title{
Preparation of DNA Ladder Based on Multiplex PCR Technique
}

\author{
Tian-Yun Wang, Li Guo, and Jun-he Zhang \\ Department of Biochemistry and Molecular Biology, Xinxiang Medical University, Henan 453003, China \\ Correspondence should be addressed to Tian-Yun Wang, wtianyuncn@126.com \\ Received 14 February 2010; Revised 26 April 2010; Accepted 11 May 2010 \\ Academic Editor: Ashis Basu
}

Copyright ( $) 2010$ Tian-Yun Wang et al. This is an open access article distributed under the Creative Commons Attribution License, which permits unrestricted use, distribution, and reproduction in any medium, provided the original work is properly cited.

\begin{abstract}
DNA molecular weight standard control, also called DNA marker (ladder), has been widely used in the experiments of molecular biology. In the paper, we report a method by which DNA marker was prepared based on multiple PCR technique. 100$1000 \mathrm{bp}$ DNA fragments were amplified using the primers designed according to the $6631 \sim 7630$ position of lambda DNA. Target DNA fragments were amplified using Touchdown PCR combined with hot start PCR, respectively, followed extracted by phenol/chloroform, precipitated with ethanol and mixed thoroughly. The results showed that the 100-1000 bp DNA fragments were successfully obtained in one PCR reaction, the bands of prepared DNA marker were clear, the size was right and could be used as control in the molecular biology experiment. This method could save time and be more inexpensive, rapid, simple when compared with the current DNA Ladder prepared means.
\end{abstract}

\section{Introduction}

It is necessary to determine the molecular weight (mw) or the base pair (bp) length of nucleic acids in the field of molecular biology. This need encompasses weights or lengths of nucleic acids from sizes ranging from mega bps down to very short oligonucleotides of only a few bp's. Traditionally the base pair length of the nucleic acid has been obtained by comparing the behavior of a nucleic acid under analysis with the behavior of another nucleic acid of defined length and usually but not necessarily of known sequence. Such methods may be electrophoresis, gel filtration chromatography, ultracentrifugation and like methods well known to those in the art. Because of the simplicity of the equipment, ease of use and resolving power to the technique, electrophoresis is the technique most frequently employed to determine the size of nucleic acids.

Double stranded DNA standards were typically prepared from DNA of bacteriophages or plasmids $[1,2]$. This process requires the propagation of the virus or plasmid in the appropriate host organism, the purification of the viral or plasmid DNA from the nucleic acids of the host, the digestion of the purified DNA with restriction endonucleases, and the purification of the resulting fragments from undigested DNA and the restriction enzyme. This process was labor, material, and equipment intensive, especially for preparation of large quantities of DNA. Restriction enzyme digested bacteriophage DNA such as Lambda was frequently employed as molecular weight markers. The array of fragment lengths in obtained bp's depended on the nature of the restriction enzyme, the DNA sequence composition, and the conditions employed. Each combination of restriction enzymes, DNA, and conditions provided a unique array of DNA fragments of defined lengths $[3,4]$.

The polymerase chain reaction (PCR) has been widely applied to the fields of molecular biology, genetics, biochemistry, genetic engineering, forensics, and the like. PCR is a simple, effectively and conveniently method and could prepare amount oligonucleotides in a very short time. However, preparing DNA ladder using common PCR was laborious. Different standard fragments were mixed according to some proportion, which were amplified and concentrated from many PCR products. So, different bands may be a standard to identify and evaluate the length of samples. However, most of DNA ladder had too many bands to be amplified by PCR, respectively, which led to great human resource, material resource, and wealth resource though which was industrialization, industry and sequencing. It is very important to 
TABle 1: Primers used in the experiment.

\begin{tabular}{lcc}
\hline Length (bp) & Primer & Position \\
\hline 1000 & 5'-GCGGCACGGAGTGGAGCAAG-3' $^{\prime}$ & 6631 \\
900 & $5^{\prime}$-GTTCGATCCGAAAGGCTGGGCGCT-3' & 6731 \\
800 & $5^{\prime}$-AAAGACCTGGGCAAAGCGGTGT-3' & 6831 \\
700 & $5^{\prime}$-TCCTGCCGCACAACACGATG-3' & 6931 \\
600 & $5^{\prime}$-ACGCCTCTGCCCGTTACCCGAA-3' & 7031 \\
500 & $5^{\prime}$-GATGAGTTCGTGTCCGTACAACTG-3' & 7131 \\
400 & $5^{\prime}$-CCGCTCGCTGGGTGAACAA-3' & 7231 \\
300 & 5'-ACGGATGAAACTGCCGGTCAGGACA-3' & 7331 \\
200 & 5'-TGGATACGTCTGAACTGGTCACGGT-3' $^{\prime}$ & 7521 \\
100 & 5'-AACGGCGTTTCGTGTCTCTGCCGGT-3' & 7531 \\
$0:$ & 5'-GTTATCGAAATCAGCCACAGGGC-3' & 7630 \\
\hline
\end{tabular}

find a new method to produce DNA ladder with a rapid, simple way to reduce costs and improve production. A new way for batch production will be described firstly in this study.

\section{Materials and Methods}

2.1. PCR Primers. According to the lambda phage DNA sequence (GenBank accession no: J02459), the sequences from $6631-7630 \mathrm{bp}$ were selected and covered. The $1000 \mathrm{bp}$ primer represents the region in length from 6631-7630, 900 bp primer from $6731-7630,800$ bp primer from $6831-$ 7630,700 bp primer from 6931-7630, 600 bp primer from 7031-7630, $500 \mathrm{bp}$ primer from 7131-7630, $400 \mathrm{bp}$ primer from 7231-7630, the $300 \mathrm{bp}$ primer from 7331-7630, the $200 \mathrm{bp}$ primer from $7431-7630$, and the $100 \mathrm{bp}$ primer from 7531-7630 of the lambda target sequence. Deoxyoligonucleotides were synthesized using phosphoramidite chemistry and were obtained from Shanghai Sangon Company, China. The primers were shown as in Table 1.

2.2. PCR Amplification and Preparation of DNA Ladder. 100$1000 \mathrm{bp}$ fragments were amplified by multiplex PCR using ten primer pairs in one PCR tube with the same sense primer. The template DNA (15-35 ng) was added to a $25 \mu \mathrm{l}$ reaction mixture containing $50 \mathrm{mM} \mathrm{KCl}, 10 \mathrm{mM}$ Tris- $\mathrm{HCl}(\mathrm{pH} 8.3)$, $2.0 \mathrm{mM} \mathrm{MgCl}, 75 \mathrm{pmol}$ of sense primer, $5 \mathrm{pmol}$ of each $100-500 \mathrm{bp}$ antisense primer, $10 \mathrm{pmol}$ of each $600-1000 \mathrm{bp}$ anti-sense primer, $0.3 \mathrm{mM}$ dNTPs, and 5 unit of Taq DNA polymerase. Taq DNA polymerase was added using hot start method. PCR was performed using a PxE (Thermo) thermocycler with a temperature profile of 35 cycles, which contained 2 cycles at $95^{\circ} \mathrm{C}$ for $30 \mathrm{~s}, 56^{\circ} \mathrm{C}$ for $30 \mathrm{~s}$, and $72^{\circ} \mathrm{C}$ for $1 \mathrm{~min}, 2$ cycles $95^{\circ} \mathrm{C}$ for $30 \mathrm{~s}, 54^{\circ} \mathrm{C}$ for $30 \mathrm{~s}$ and $72^{\circ} \mathrm{C}$ for $1 \mathrm{~min}, 2$ cycles for every annealing temperature interval 2 temperature, until $44^{\circ} \mathrm{C}$ polishing 35 cycles. PCR products were detected by $2 \%$ agarose gel with $120 \mathrm{~V}$ voltages for $40 \mathrm{~min}$.

$5 \mu \mathrm{l}$ of each PCR reaction mixture was screened on $2 \%$ agarose gel electrophoresis and the length was estimated by comparing the known size DNA marker (Sangon), then was purified and sequenced by Sangon Company. The PCR products were extracted through phenol/chloroform and precipitated with ethanol, and then analyzed their UV absorbance under $260 \mathrm{~nm} .5 \mu \mathrm{l}$ aliquot of the material was electrophoresed and no change in the band migration pattern or band intensities was observed following ethidium bromide staining. The marker was then frozen at $-20^{\circ} \mathrm{C}$.

\section{Results and Discussion}

All fragments of 100-1000 bp were amplified successfully with multiplex PCR way by optimizing process in the PCR reaction system and temperature profile (Figure 1). Finally, with the help of touch down PCR and hot start PCR technique, all the ten DNA fragments were obtained by multiplex PCR. At first, the same amount of ten primer pairs were added to a reaction system, and the annealing temperature profile from $58^{\circ} \mathrm{C}$ to $48^{\circ} \mathrm{C}$ for 30 cycles (Figure $1(\mathrm{a})$ ), and the annealing temperature profile from $58^{\circ} \mathrm{C}$ to $48^{\circ} \mathrm{C}$ for 35 cycles (Figure 1(b)), 100-500 bp fragments were amplified by this method. Adjusting the amount of the ten anti-sense primers and the annealing temperature profile from $56^{\circ} \mathrm{C}$ to $46^{\circ} \mathrm{C}$, most of target fragments were detected. (Figure 1(c)) Finally, raising the amount of 600-700 bp anti-sense primers and using the annealing temperature profile from $56^{\circ} \mathrm{C}$ to $44^{\circ} \mathrm{C}$, all the target fragments were amplified and nonspecific fragments disappeared (Figure 1(d)).

PCR has become a widely used tool for detection, identification, and differentiation of pathogenic microorganisms in diagnosis of animal and human diseases or other studies [5]. More and more derived PCR techniques were devised for different study purpose, for instance, multiplex PCR technique, which has been widely used to detect and identify some unknown and possible pathogenic microorganisms in some diseases. Using several primer pairs, each having a particular specificity, in the same reaction added a multidimensional perspective to the diagnostic potential of PCR. Such a procedure allowed simultaneous detection of two or more different microbial agents in a single sample and the inclusion of internal controls. As multiplex PCR involved a far more complex reaction system than the normal 


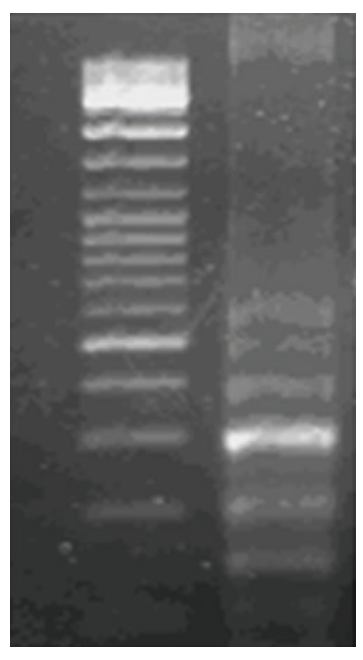

M

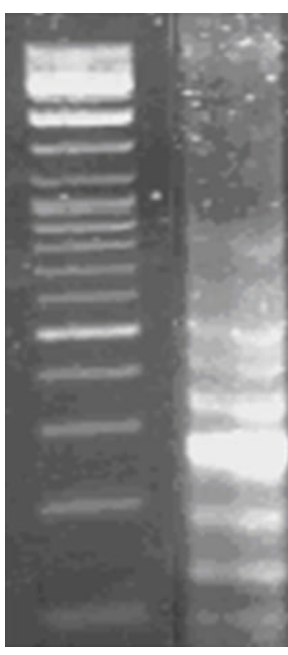

M

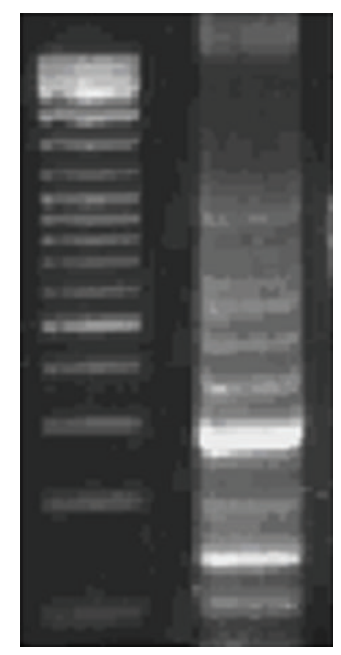

M

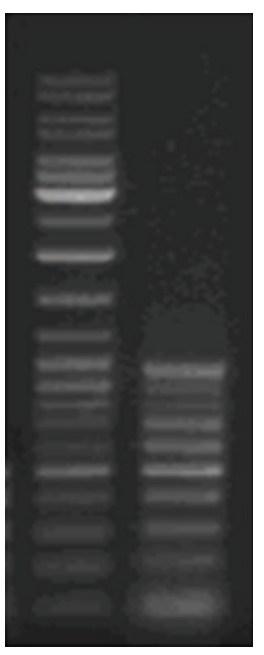

M

(d)

FIGURE 1: Illustrations of the PCR products for adjusting reaction system and temperature profile. 100-1000 bp fragments were amplified by multiplex PCR using 10 primer pairs in a PCR tube which have the same sense primer. (a) the annealing temperature profile from $58^{\circ} \mathrm{C}$ to $48^{\circ} \mathrm{C}$ for 30 cycles; (b) 100-500 bp fragments were amplified under the annealing temperature profile from $58^{\circ} \mathrm{C}$ to $46^{\circ} \mathrm{C}$ for $35 \mathrm{cycles}$. (c) Adjusting the amount of the ten anti-sense primers and the annealing temperature profile from $56^{\circ} \mathrm{C}$ to $46^{\circ} \mathrm{C}$, most of target fragments were detected; (d) Raising the amount of 600-700 bp anti-sense primers and using the annealing temperature profile from $56^{\circ} \mathrm{C}$ to $44^{\circ} \mathrm{C}$, all the target fragments were amplified and nonspecific fragments disappeared.

simplex mode, so its performance was more difficult to predict and could be assessed only after extensive trials [5]. Thus, quite a number of currently used protocols could be further optimized to exclude nonspecific reactions. In the present paper, ten primer pairs was added to a reaction system to amplify ten different fragments. We optimized the reaction system and reaction to avoid nonspecific reactions and primer dimer, target sequences as defined by primer binding sites had been checked carefully in order to insure high specificity of detection. In addition, using hot start and touch down PCR method, adjusting the quantity of each primer and annealing temperature were available to improve the performance of the amplification reaction. The basic idea of hot-start PCR was to reduce nonspecific amplification in the initial phase by releasing active enzyme only immediately before the first primer binding step [6]. Another kind of PCR, touch down PCR could design a continuous and touchdown annealing temperature range to amplify some fragments [7]. This approach was designed to prevent primer dimer formation, mispriming, and spontaneous initiation of DNA strand synthesis [8]. Finally, with the undisputed success ten fragments based on the multiplex PCR with touch down PCR and hot start were amplified and detected clearly (Figure 1).

Compared with conventional methods for producing DNA Marker, multiplex PCR method could reduce costs and raise production in laboratory once. Undoubtedly the demand for multiplex PCR method is going to increase further purpose in future because of the potential to reduce costs, human and material resource, and raise throughput in the same time for batch production.

\section{Acknowledgments}

This work was partly supported by the grants from the Natural Science Foundation of Henan Province, China (no. 511042300, 624410041) and Science \& Technology Innovation Talents in University of Henan Province (2008HASTIT026).

\section{References}

[1] L. J. Wei, Y. T. Wei, X. F. Huang, X. Q. Wei, and R. B. Huang, "Construction of a new kind of DNA marker vector," Biotechnology, vol. 14, no. 5, pp. 33-35, 2004.

[2] C. J. Zhu, Q. Y. Wei, W. L. Qu, and H. Ding, "Experimental study on making a new DNA marker from positive and negative DNA samples," Acta Medicinae Sinica, vol. 18, pp. 937-938, 2005.

[3] Hyman, "DNA ladders," US Patent no. 5,840,575, 1999.

[4] A-li W. Hu, J. L. Hartley, and H. J. Jordan, "Nucleic acid ladders," US Patent no. 6,924,098, 2005.

[5] J. L. Hartley, "Nucleic acid marker ladder for estimating mass," US Patent no. 7,132,520, 2006.

[6] Dawson, "Method for the multiplexed preparation of nucleic acid molecular weight markers and resultant products," US Patent no. 5,714,326, 1998.

[7] D. J. Korbie and J. S. Mattick, "Touchdown PCR for increased specificity and sensitivity in PCR amplification," Nature Protocols, vol. 3, no. 9, pp. 1452-1456, 2008.

[8] I. Smolina, C. Lee, and M. Frank-Kamenetsk II, "Detection of low-copy-number genomic DNA sequences in individual bacterial cells by using peptide nucleic acid-assisted rollingcircle amplification and fluorescence in situ hybridization," Applied and Environmental Microbiology, vol. 73, no. 7, pp. 2324-2328, 2007. 

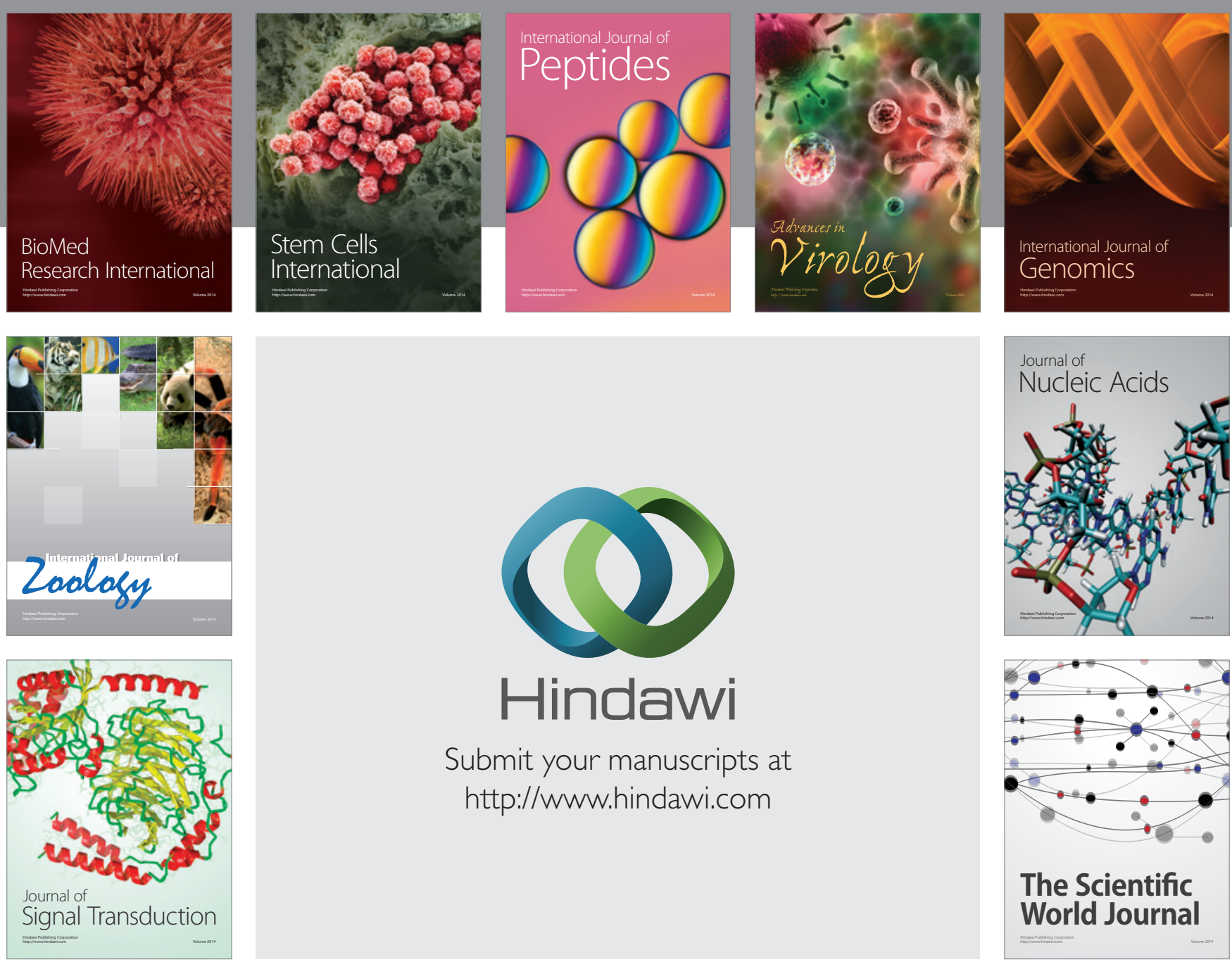

Submit your manuscripts at

http://www.hindawi.com
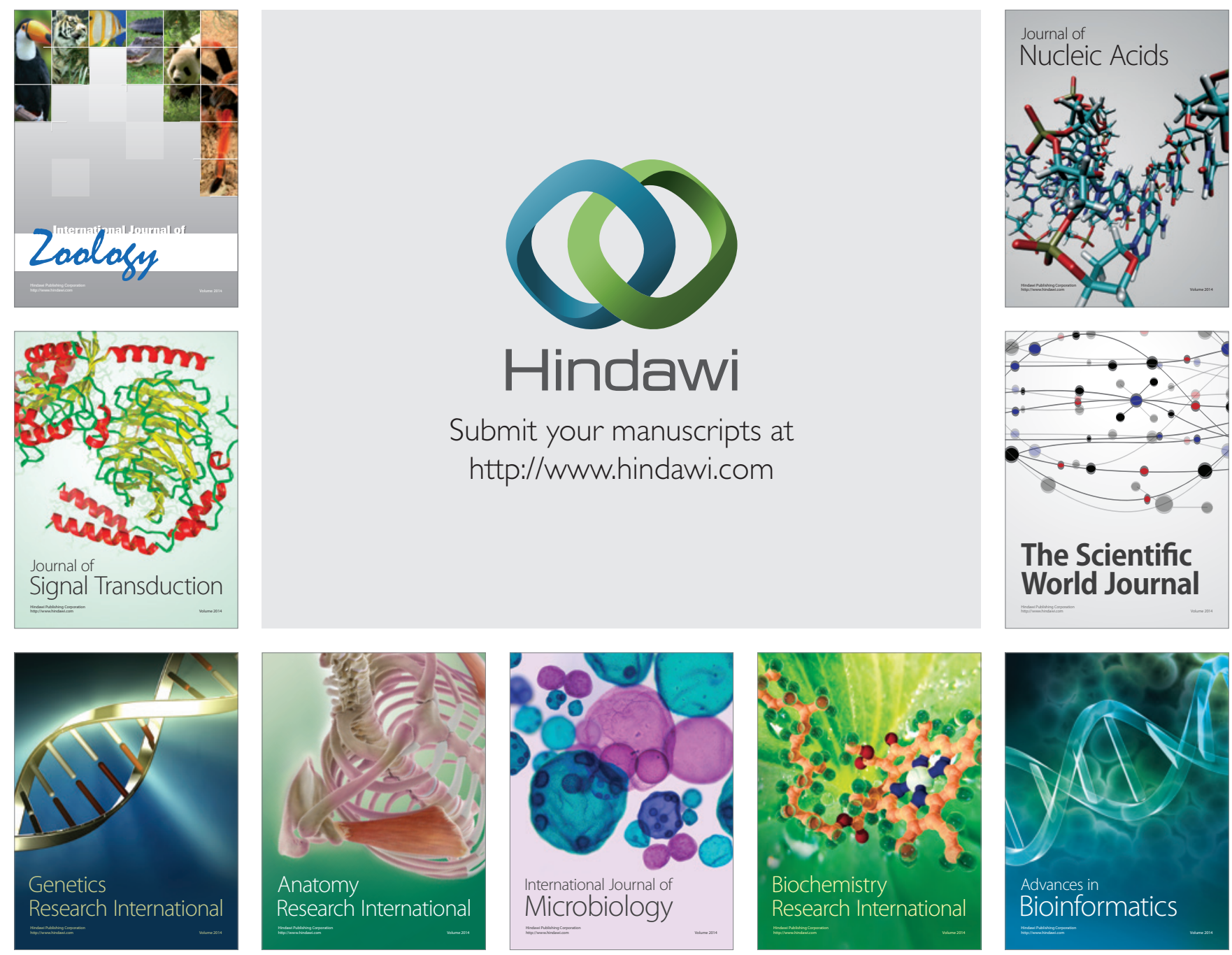

The Scientific World Journal
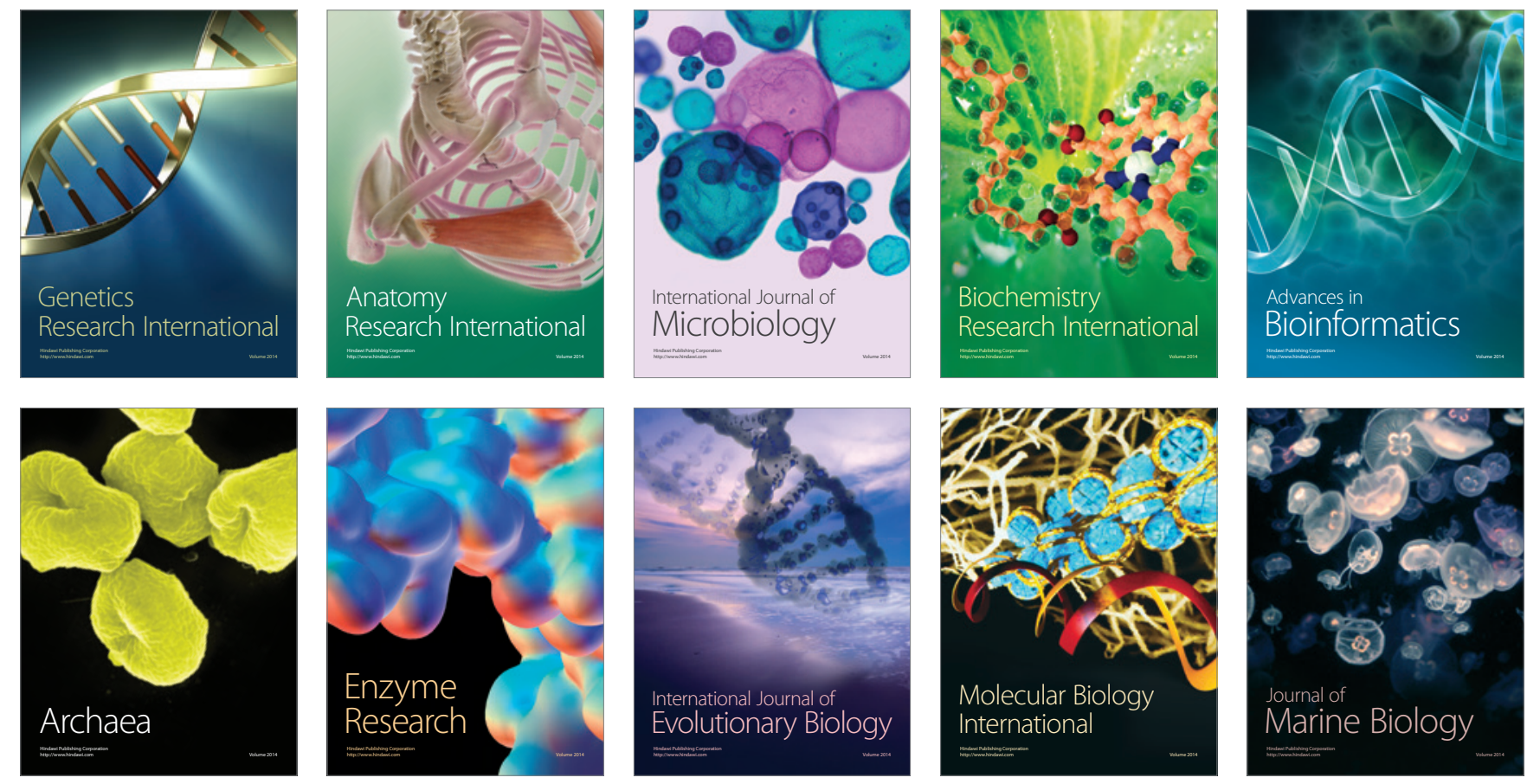